\title{
Aesthetics as a Foundation for Business Activity
}

\begin{abstract}
This paper identifies the ultimate justification for business activity as an aesthetic justification. Aesthetics, loosely defined as the appreciation of beauty, subsumes both ethics and economics within an holistic justificatory mechanism for business decisions.Five essential qualities of aesthetic judgment are identified: disinterest, subjectivity, inclusivity, contemplativity, and internality. The quality of aesthetic judgment, exercised by the individual through the organization, will determine the extent to which business activity enhances quality of life.
\end{abstract}

KEY WORDS: ethics, aesthetics, virtue corporate objective, beauty

"The existence of the world is justified only as an
aesthetic phenomenon." - Nietzsche

The high seriousness of aesthetic value could perhaps be established in two stages first, by showing that aesthetic preferences are not merely private and personal but may be correct and incorrect: and second, by linking them, if only indirectly, to overriding moral values or some more general notion of the 'good life'. [Whewell, 1995, p. 8]

The end of history, in the sense of the clearing away of modernist ideologies, has left the west in a postmodern vacuum increasingly filled by the ideals of commercial exchange. As consumer, shareholder, stakeholder, employee, etc., we are all now 'in

John Dobson is Professor of Finance at California Polytechnic State University. His primary area of interest is financial ethics, in particular how the theory of ethics relates to financial side of business activity. He has published articles on ethics and finance in various academic journals, and has published two books, both of which investigate the synthesis of finance and ethics. His current research focuses on the connections between psychology, finance theory, and moral philosophy. business'. Thus the 'public' corporation, competing and cooperating with other public corporations in a market economy, increasingly dominates our world. How can such a form of organization be justified? What ultimate goal should such a form of organization enable humanity to pursue? On a practical level, on what basis, by which criteria, should decisions be made in business?

This latter question recognizes that even the smallest issues in day-to-day business are intertwined with the biggest philosophical questions. Just as any decision we make in our individual lives rests, for its ultimate justification, on some notion of the good life for us; so any micro-business decision rests, for its ultimate justification, on some macro-business philosophy.

The aesthetic perspective provides a way of answering this fundamental question. This paper shows how aesthetics provides a unified view of the nature and purpose of business that overcomes the incoherencies and inconsistencies of the ethical or economic view of business. As such, aesthetics also provides a justificatory mechanism for decisionmaking in business. This is an ultimate justificatory mechanism in the sense that, once the aesthetic criteria are addressed, no further justification is required. Consider these three basic questions relating to a decision in or on business:

1. Is it profitable?

2. Is it ethical?

3. Is it beautiful?

At first blush, the third question - Is it beautiful? might appear odd, out of place, perhaps trivial in comparison to questions one and two. What this paper demonstrates, however, is that, when beauty is adequately defined, the third question becomes the most fundamental criterion of the three. That is, the 
third question most closely relates to the ultimate justification for business activity. Aesthetics provides this ultimate justification through the application of certain qualities of aesthetic judgment that, taken together, define the aesthetic perspective.

The link between economics, ethics, aesthetics, and some notion of quality of life is well established in philosophy: in A Companion to Aesthetics, Hegel argues "the highest act of reason, the one through which it encompasses all ideas, is an aesthetic act and ... truth and goodness only become sisters in beauty" (Hegel, 1995, p. 182); in On The Aesthetic Education of Man, Schiller claims that " $\ldots$ logic rest $[s]$ on ethics, and ethics on aesthetics" (p. clxxxix); and more recently Foucault asks the question, "Couldn't everyone's life become a work of art? Why should the lamp or the house be an art object, but not our life?" (p. 350).

Five qualities that define aesthetic judgment are defined below: disinterest, subjectivity, inclusivity, contemplatively, and internality. The central argument of this paper is that, by making decisions on the basis of these five criteria - in addition to the conventional economic and moral criteria - managers will better align business activity with societal quality of life.

\section{The postmodern shift}

Much has been written about the broad cultural shift that the west experienced in the 20th century from modernism to postmodernism. These shifts are never clear and unambiguous, but what in essence occurred was a 'decenterring' of western culture. Postmodern culture recognizes no single metaphysical center, only perspectives. Nothing exists beyond the text, or the context.

What are the implications of postmodernism specifically for business? A decentering in our broad cultural conception of business means a questioning of the modernist conception of business as solely an economic pursuit. Neoclassical economic theory, which provided the conceptual foundation for modern business, faced what Alasdair MacIntyre labels an "epistemological crisis":

At any point it may happen to any tradition-constituted enquiry that by its own standards of progress it ceases to make progress. Its hitherto trusted methods of enquiry have become sterile. Conflicts over rival answers to key questions can no longer be settled rationally. Moreover, it may indeed happen that the use of the methods of enquiry and of the forms of argument, by means of which rational progress had been achieved so far, begins to have the effect of increasingly disclosing new inadequacies, hitherto unrecognized incoherencies, and new problems for the solution of which there seem to be insufficient or no resources within the established fabric of belief... This kind of dissolution of historically founded certitudes is the mark of an epistemological crisis. [After Virtue, 1984, p. 362]

This epistemological crisis is being faced by both of the modernist justification frameworks for business, namely economics and ethics: neoclassical economics, and modernist analytical moral philosophy, are both facing much publicized "incoherencies" and "inadequacies" in the face of the contemporary postmodern critique. For these disciplines truth has become, as Nietzsche predicted, "a mobile army of metaphors, metonyms, and anthropomorphisms" (WP, 1967, p. 897). Indeed, in contrast to the recent epochs of the age of reason and of self-confidence, the west of the next millennium promises to be an age of self-doubt and self-questioning. Jean Staune sums up this transition by noting that

one of the great events of the end of the twentieth century is that, in all the disciplines of science, a new vision is emerging. Behind the study of the foundations of matter, the origin of the universe, behind the experiments studying how man's consciousness works, behind the playing out of the evolution of life appears a certain depth to reality. One can scientifically show that 'what is' cannot be reduced to an objective, material and measurable level. [1996, p. 146]

In business this current age of self-questioning is reflected in the growing debate over the role of business in society. It is no longer obvious to our culture exactly what the role of business and the business manager is in society. Should business simply try to make a profit and let the logic of the Smithian invisible hand do the rest? Or must postmodern business actually in some way nurture a utopian concept of society? Indeed is there still any meaningful concept of society that is wholly divorced from business? Is our culture now merely in a literal sense 'corporate' culture? Staune encapsulates 
this shift by noting three broad cultural realizations that characterized the end of the 20th century:

- The hope of being able to explain reality by reality, to find a definitive explanation for what is real, has vanished.

- The cutting edge of the sciences studying matter reveals the presence of an intangibility, another level of reality whose existence can be perceived but not reached.

- The question of meaning (of our own existence, of the existence of the universe) is once again at the heart of contemporary science after having been excluded for centuries. [1996, p. 146]

Staune goes on to conclude that taken together these factors create a cultural impact that "constitutes a real 'change of paradigm', in other words a change in the way we see things... such a change of vision cannot fail to have an impact on our society given the role that science plays" (1996, p. 147). The postmodern condition, therefore, is a condition of fundamental epistemological openness. This openness enables aesthetic judgment to be privileged because, unlike economic or moral judgment, aesthetics does not rest on any logical construct; any truth claim. The valuation of beauty as an ultimate good is a primordial valuation: one requiring no rational or logical valediction. As Iris Murdoch reminds us: "Goodness and beauty are not to be contrasted, but are largely part of the same structure. Plato, who tells us that beauty is the only spiritual thing that we love immediately by nature, treats the beautiful as an introductory section of the good" (1980, p. 41).

\section{Qualities of aesthetic judgement}

Aesthetic judgment will tap directly into a meaningful notion of quality of life in the postmodern world. As mentioned above, the five essential qualities that define aesthetic judgment are disinterest, subjectivity, inclusivity, contemplativity, and internality. Each of these qualities can be defined as follows:

- Disinterest; aesthetic interest in an object is the purest form of interest in that it is entirely exhaustive and self-contained. Aesthetic interest is an end in itself that requires no further justification. We pursue beauty, either individually or collectively, for its own sake alone. As such, aesthetic beauty is the purest definition of quality of life. Unlike economic judgment, which is premised on the accumulation and enhancement of material wealth, or moral judgment, which is premised on the application of some moral principle, aesthetic judgment rests on no ulterior logical premise or rational objective. Our interest in aesthetic beauty, like our interest in quality of life, is our ultimate interest to which all other interests - economic, moral, or otherwise - are strictly instrumental.

- Subjectivity; aesthetics concerns the relationship between the object, and the subject judging the object. There is indeed inferior and superior aesthetic judgment, but this quality relates to the relation of subject to object. It does not inhere entirely with one or the other. Aesthetic judgment can be applied universally; it applies to all and in all aspects of human endeavor. Thus, for its exercise, aesthetic judgment requires no extant and exogenous body of knowledge: some objective truth claim, or premise of progress or particular purpose.

- Inclusivity; aesthetic judgment is an intellectually pure form of judgment in the sense that it can consider all aspects of a phenomenon. It is nonprejudicial in the sense that it is open to all perspectives and contexts. All individuals, regardless of gender or culture, exercise aesthetic judgment.

- Contemplativity; aesthetic judgment is nonhedonistic in the sense that it involves more than merely the pursuit of pleasure. Aesthetic judgment is educatable and involves contemplation on all aspects of the phenomenon being judged.

- Internality; the goods of aesthetic judgment, in terms of the appreciation of beauty, are internal in the sense that they are created by the individual. They require no tangible external resources and as such are unlimited in supply, and so are not the source of competition.

\section{The link to virtue ethics}

In addition to defining the characteristics of aesthetic judgment, the above list also illustrates the close link between aesthetic judgment and one particular 
branch of moral philosophy, namely virtue ethics. It is no coincidence that virtue ethics finds its origins in classical Greece, and is as such a premodern approach to ethics. It is therefore not surprising that virtue ethics is experiencing a revival in our contemporary postmodern condition (Dobson, 1999; MacIntyre, 1984). Indeed, the remainder of this paper will show how the language of virtue ethics enables us to ground aesthetic judgment in a framework that can provide a practical goal for management.

\section{The role of virtue ethics/aesthetics in business}

Virtue ethics is concerned primarily with the pursuit of a certain type of excellence or, in the aesthetic context, the pursuit of a certain definition of beauty. This link between beauty and excellence is replete in Plato's Republic. In commenting on Plato, Iris Murdoch notes that the "appreciation of beauty is also a completely adequate entry into the good life" (1980, pp. 64-65). More recently this link was noted by Voltaire in his essay on taste: "[aesthetic] reflection, relishes the good, rejects the contrary, and requires force of habit to give it fixed and uniform determination" (1997, p. 5). Similarly, in his book 'Art as Experience', John Dewey notes that " $[\mathrm{t}] \mathrm{he}$ enemies of the [a]esthetic are neither the practical nor the intellectual. They are the humdrum; slackness of loose ends; submission to convention in practice and intellectual procedure. Rigid abstinence, coerced submission, incoherence and aimless indulgence" (1934, p. 50).

Virtue ethics' primary attribute is a strong emphasis on the importance of certain generally accepted virtues or excellences of character, what Voltaire might have referred to as 'tastes'. For Voltaire it would have been through honing and perfecting these tastes that an individual attains the ability, the excellence of taste, necessary to exercise aesthetic judgment. In virtue ethics it is through exercising these virtues that one flourishes as an individual; one attains a high quality of life. MacIntyre notes that "virtues therefore are to be understood as those dispositions that will enable us to achieve the goods internal to practices". The notion of an internal good/excellence is central to virtue ethics. Martha Nussbaum defines this good/ excellence as "the end of all desires, the final reason why we do whatever we do; and it is thus inclusive of everything that has intrinsic worth, lacking in nothing that would make a life more valuable or more complete" (1991, p. 38). What Nussbaum is describing here, albeit inadvertently, is the aesthetic perspective. Consider the central characteristics of internal goods:

1. They are universally attainable by one who is educated in the virtues, yet their particular qualities are specific to a particular activity. For example, in the context of the game of chess, MacIntyre defines the internal goods as "those goods specific to chess, the achievement of a certain highly particular kind of analytical skill, strategic imagination and competitive intensity" (1984, p. 188).

2. They are unlimited in supply. Thus my achievement of the internal good or aesthetic appreciation of a particular activity in no way limits your ability to attain similar appreciation.

3. They are intangible in the sense that they do not readily lend themselves to simple definition, quantification, or mathematical enumeration. In other words they are very 'unfriendly' to modernism.

All of these characteristics apply equally well to the goods of virtue ethics, or to the goods of aesthetic judgment. As Plato observed above, in a world not subject to the prejudices of modernism, goodness is beauty. The right appreciation of beauty, in business as elsewhere, can lead us to make good decisions: decisions that enhance quality of life.

\section{The aesthetic firm}

Examples are increasingly coming to light of managers at large corporations making decisions on the basis of criteria that, though not always officially recognized as such, can best be described as aesthetic.

In her book, The Substance of Style, Virginia Postrel notes that GE (formerly General Electric), the world's largest conglomerate, believes that global corporate culture is "entering an era in which the look and feel of products will determine their suc- 
cess. Sensory, even subliminal, effects will be essential competitive tools" (2003, p. 2). Postrel notes how the recent experiences of other major corporations bear out GE's prediction. Her list includes Apple Computer's use of bright colors, Target's increasing use of designer products at its retail outlets, Visa's use of designer credit cards, and many other examples. Postrel quotes Starbuck's CEO, Howard Schultz: "Every Starbucks store is carefully designed to enhance the quality of everything the customers see, touch, hear, smell, or taste. All the sensory signals have to appeal to the same high standards. The artwork, the music, the aromas, the surfaces all have to send the same subliminal message as the flavor of the coffee " (p. 20).

Conversely, failure on the part of management to recognize this 'aesthetic shift' can prove costly. Consider a recent decision made by management at Royal Dutch-Shell in the wake of lackluster stock performance and faltering public image. Robert Cozine notes that Shell "plans to shake up its tradition-bound corporate culture by increasing the number of women and range of nationalities in its top management tier" (1998); currently only about 4\% of Shell's 400 senior managers are women. The main reason for this shake up, according to Cozine, is that the -

narrowness of Shell's senior management base has been cited by critics as one reason why it has struggled with rapid change in its business. Critics point to the controversy over the scrapping of the Brent Spar oil rig and Shell's problems with human rights in Nigeria. They say a broader management base might have helped Shell to respond more effectively to those issues. [Ibid.]

Was Shell's decision founded on economics, ethics, or some other criterion? Consider the thrust of Arie de Geus's recent book The Living Company. De Geus, who worked as a manager at Shell for some 40 years, observes his company moving away from a narrow conceptualization of itself as solely or even primarily an economic enterprise: "The twin policies of managing for profit and maximizing shareholder value, at the expense of all other goals, are vestigial management traditions" (1997, p. 15).

PepsiCo has recently suffered a public relations disaster that resulted in it severing all ties with Burma, a country currently controlled by a military junta. Pepsi's interests in Burma were no doubt financially justifiable initially, but Pepsi failed to realize that naive financial justifiability is not sufficient today. Nike is having similar experiences with its (a priori economically rational) policy of targeting certain developing countries as locations for shoe assembly. Through the infamous 'sweatshop scandal' Nike has discovered that the 'image' - in addition to the economic substance - of its operations in developing countries is now all important.

In essence, Pepsi, Shell, and Nike tried to remain predominantly economic institutions within a culture that increasingly finds this unacceptable. For sure economic criteria play a role, every firm must generate positive cash flow, but increasingly the firm's ability to generate profits rests on non-economic criteria. Managers must value what society values, and society values aesthetics. So the decision criteria listed earlier in this paper - namely disinterest, subjectivity, inclusivity, contemplativity, and internalitywill awaken managers to the holistic approach increasingly required in contemporary business: Is it profitable? Is it ethical? Is it BEAUTIFUL?

\section{Conclusion: the need for aesthetic education}

In the Politics, Aristotle identified as an educational failure " a tendency on the part of individual citizens to identify as the good and the best some good which is merely an external by-product of those activities in which excellence is achieved" (Politics 1257b401258a14; NE 1095b22-31). The educational challenge in business, therefore, is to distinguish between the true ultimate objective, namely aesthetic virtue-guided excellence, and the by-product, namely material wealth. Sherwin Klein recently described a new type of corporate managerial goal along these very lines:

The ideal of craftsmanship is to create that which has quality or excellence; personal satisfaction, pride in accomplishment, and a sense of dignity derived from the consequent self-development are the motivations. In an 'excellent' company it is this ideal that permeates the firm, and management should provide the moral example of such an ideal; a business management craftsman attempts to create a quality organization, and quality products and services are the result of such an organization. [1998, p. 55]

The key words of the modernist business universe of the past 150 years may have been those of logic, 
reason, science, technical expertise, instrumental rationality, wealth maximization, and moral rectitude. But the key concepts of the aesthetic business era will be such things as harmony, balance, sustainability, aesthetic excellence, judgment, context, compassion, community, beauty, and art. Those corporate cultures that recognize this shift will flourish both financially and aesthetically, and will genuinely contribute to quality of life. Those that don't will, and indeed should, founder and perish.

\section{References}

Cozine, R.: 1998. 'More top Shell Jobs for Women', Financial Times, January 13, p. 17.

De Geus, A.: 1997, The Living Company (HBS Press, Cambridge Mass).

Dewey, J.: 1934, Art as Experience (G Putnam's and Sons, New York) pp. 50.

Dobson, J.: 1999, The Art of Management and the Aesthetic Manager (Quorum Books, New York).

Foucault, M.: 1984, 'On the Genealogy of Ethics: An Overview of Work in Progress', in Foucault Reader, Rainbow (ed.) (Newyork, Pantheon).

Hegel, G. W. F.: 1997, in David Cooper (ed.), A companion to Aesthetics (Oxford: Blackwell).
Klein, S.: 1998, 'Don Quixote and the Problem of Idealism and Realism in Business Ethics', Business Ethics Quarterly 8(1), 43-64.

MacIntyre, A.: 1984, After Virtue (University of Notre Dame Press, Notre Dame Indiana).

Nietzsche, F.: 1967, in W. Kaufmann (ed.), The Will to Power, trans. W. Kaufmann and R. J. Hollingdale (Random House, New York) para 1067, pp. 449-450.

Nussbaum, M. C.: 1991 'The Chill of Virtue', The New Republic September 16 \& 23, 34-40.

Postrel, V.: 2003, The Substance of Style (Harper Collins, New York).

Schiller, F.: 1967, in E. M. Wilkinson and L. A. Willoughby (eds.), On The Aesthetic Education of Man (Oxford University Press, Oxford U.K.).

Staune, J.: 1996, 'Science and Management: An Introduction', CEMS Business Review 1, 145-150.

Voltaire: 1997, 'The Essence of Taste', in S. Feagin and P. Maynard (eds.), Aesthetics (OUP).

Whewell, D.: 1995, A Companion to Aesthetics, ed. david Cooper (Blackwell, Oxford).

Finance

California Polytechnic State University,

College of Business

San Luis Obispo, CA 93407,

U.S.A. 